\title{
Pelatihan Massage Bayi Dan Anak Balita Pada Ibu-Ibu Perumahan Muhajirin Asri 2 Desa Terong Tawah Kecamatan Labu Api Kabupaten Lombok Barat
}

\author{
Indri Susilawati; Balqis Ratu Nurul L.E; Muhammad Satria Mulyajaya \\ Universitas Pendidikan Mandalika
}

\begin{abstract}
Abstrak; Massage merupakan tindakan instingtif untuk meringankan sakit, letih, lesu, terlebih apabila dilakukan oleh seorang ibu terhadap anaknya. Massage merupakan salah satu bentuk dari terapi sentuh yang berfungsi sebagai salah satu teknik pengobatan penting. Massage bayi merupakan seni perawatan kesehatan dan pengobatan yang dikenal sejak awal manusia diciptakan di dunia serta telah dipraktekkan sejak berabad-abad tahun silam secara turun temurun oleh dukun bayi. Massage bayi merupakan suatu kegitan yang dilakukan oleh orang tua sebagai tindakan menstimulasi pertumbuhan dan perkembangan bayi. Sentuhan dan pandangan mata antara orang tua dan bayi mampu mengalirkan kekuatan jalinan kasih sayang diantara keduanya yang merupakan dasar komunikasi untuk memupuk cinta kasih secara timbal balik, mengurangi kecemasan, meningkatkan kemampuan fisik serta rasa percaya diri. Karena massage bayi ditujukan untuk memijat bayi, maka sebelum memijat perlu diketahui terlebih dahulu susunan (anatomi) dan tata kerja (fisiologi) dari organ manusia. Beberapa organ yang perlu diketahui adalah otot, peredaran darah, saraf, alat dalam dan kelenjar. Otot kerangka biasanya dikaitkan pada dua tempat tertentu, yaitu tulang, tulang rawan, ligament dan kulit.
\end{abstract}

Kata Kunci: Pelatihan, Massage, Bayi, Anak Balita.

\section{PENDAHULUAN}

Anak memiliki nilai yang sangat tinggi untuk keluarga dan bangsa. Setiap orang tua mengharapkan anaknya dapat tumbuh dan berkembang secara optimal sehingga dapat menjadi sumber daya manusia yang berkualitas dan tangguh. Tercapainya pertumbuhan dan perkembangan yang optimal merupakan hasil interaksi berbagai faktor yang saling berkaitan, yaitu faktor genetik, lingkungan, perilaku, dan rangsangan atau stimulasi yang berguna (Dasuki, 2003: 3). Terapi sentuh, terutama masase menghasilkan perubahan fisiologis yang menguntungkan, dapat diukur secara ilmiah dan dapat mengurangi kelelahan pada bayi dan anak balita. Ikatan batin yang sehat (secure attachment) sangat penting bagi anak terutama dalam usia 2 tahun pertama yang akan menentukan perkembangan kepribadian anak selanjutnya. Selain faktor bawaan yang dianugerahkan Tuhan sejak lahir, stimulus dari luar juga berperan bagi pertumbuhan fisik dan perkembangan emosional anak. Saat bayi berumur 3 bulan, bayi dapat mengangkat kepala dan tubuhnya jika diletakkan dalam posisi tengkurap. Memegang mainan dengan kedua tangannya. Bayi melihat kesana- kemari, dan bayi akan mencoba mencari suara atau musik jika mendengarnya. Bayi dapat duduk dalam beberapa waktu jika ditunjang.

Menurut Wara Kushartanti (2004: 1) bahwa pijatan merupakan tindakan instingtif untuk meringankan sakit, letih, lesu, terlebih apabila dilakukan oleh seorang ibu terhadap anaknya. Massage merupakan salah satu bentuk dari terapi sentuh yang berfungsi sebagai salah satu teknik pengobatan penting. Bahkan menurut penelitian modern, massage bayi secara rutin akan membantu tumbuh kembang fisik dan emosi bayi, di samping mempertahankan kesehatannya. Massage pada bayi dan anak balita ini lebih ke gerakan mengusap saja, yang dilakukan secara rutin. Mekanisme dasar dari massage pada bayi dan anak balita belum banyak diketahui. Walaupun demikian, saat ini para pakar sudah memiliki beberapa teori tentang mekanisme ini serta menemukan jawabannya. Sentuhan dan pijat pada bayi dan anak balita setelah kelahiran dapat memberikan jaminan adanya kontak tubuh berkelanjutan yang dapat mempertahankan perasaan aman pada bayi dan anak balita. Kulit merupakan organ tubuh yang berfungsi sebagai reseptor terluas. Sensasi sentuh atau raba adalah indera yang 
aktif berfungsi sejak dini, karena bayi dan balita telah merasakannya sejak masa janin, yaitu ketika dikelilingi dan dibelai oleh cairan hangat ketuban. Ujung-ujung saraf pada permukaan kulit akan bereaksi terhadap sentuhansentuhan dan selanjutnya mengirimkan pesan-pesan ke otak melalui jaringan saraf di tulang belakang. Sentuhan juga akan merangsang peredaran darah dan akan menambah energi karena gelombang oksigen yang segar akan lebih banyak dikirim ke otak dan seluruh tubuh.

Ilmu kesehatan modern telah membuktikan secara ilmiah bahwa terapi sentuhan dan massage pada bayi mempunyai banyak manfaat terutama bila dilakukan sendiri oleh orang tua bayi. Penelitian tentang pengaruh massage bayi terhadap kenaikan berat badan bayi memperoleh hasilbahwa pada kelompok kontrol kenaikan berat badan sebesar 6,16\% sedangkan pada kelompok yang dipijat 9,44\% (Dasuki, 2003: 5). Di Indonesia pelaksanaan massage bayi di masyarakat desa masih dipegang peranannya oleh dukun bayi. Selama ini pemijatan tidak hanya dilakukan bila bayi sehat tetapi juga pada bayi sakit atau rewel dan sudah menjadi rutinitas perawatan bayi setelah lahir (Sari, 2004: 1).

Selama ini banyak pedoman cara massage bayi usia 0 sampai 3 tahun dengan berbagai teknik, tetapi belum ada pedoman massage bayi usia 3 bulan sampai 3 tahun untuk mengurangi kelelahan. Massage yang dikembangkan dalam penelitian ini berisikan variasi teknik massage bayi yang aman. Manipulasi massage yang biasa digunakan secara umum berisikan efflurage (menggosok), friction (menggerus), Tapotement (memukul), walken, skin rolling (melipat kulit), sedangkan pada dan getaran (fibration). Penelitian ini merupakan penelitian dan pengembangan karena mengadopsi model massage bayi yang sudah ada dan dimodifikasi.

Target dari program pengabdian masyarakat "Pelatihan Massage Bayi Dan Anak Balita Pada Ibu-Ibu Perumahan Muhajirin Asri 2 Desa Terong Tawah Kecamatan Labu Api Kabupaten Lombok Barat " adalah sebagai berikut:
1. Program ini diperuntukkan khusnya bagi ibu-ibu dikalangan Perumahan Muhajirin Asri 2 yang mempunyai bayi dan anak balita.

2. Memberikan pengetahuan dan keterampilan bagi ibu-ibu khusunya di kalangan Perumahan Muhajirin Asri 2 tentang massage pada bayi dan anak balita.

3. Meningkatkan kesadaran tentang manfaat massage bayi dan anak balita.

4. Meningkatkan partisipasi orang tua terhadap tumbuh kembang anak.

\section{Luaran}

1. Orang tua khusunya ibu-ibu memiliki pemahaman tentang manfaat massage bayi dan anak balita.

2. Ibu-ibu dapat melakukan sendiri massage pada anaknya.

3. Menambah pengetahuan dan keterampilan ibu-ibu dalam melakukan massage pada bayi dan anak balita.

4. Menambah kedekatan antara Ibu dan anaknya

\section{METODE PELAKSANAAN}

\subsection{Persiapan dan Pembekalan}

a. Persiapan Kegiatan

1. Melakukan pendataan ibu-ibu di Perumahan Muhajirin Asri 2 yang memiliki bayi dan anak balita.

2. Memberikan pembekalan kepada para peserta yang sudah didata tentang kegiatan yang akan dilaksanakan.

3. Mempersiapkan media atau alat yang akan di gunakan pada saat program kegiatan berlangsung seperti boneka, bedak bayi, baby oil atau minyak zaitun, handuk kecil atau wash lap, ember kecil, tisu (basah dan kering) dan air hangat.

\subsection{Pelaksanaan Program}

Adapun tahapan pelaksanaan program

kegiatan sebagai berikut:

1. Menunjuk anggota yang akan menjadi moderator, fasilitator dan demonstrator massage.

2. Penyajian materi massage.

3. Praktek pelatihan massage.

4. Evaluasi kegiatan.

Kegiatan ini berlangsung pada hari sabtu tanggal 22 September 2019 yang bertempat Perumahan Muhajirin Asri 2. 
Tabel 4.2. Susunan Acara Kegiatan

\begin{tabular}{|l|l|l|}
\hline Waktu & Kegiatan & Keterangan \\
\hline $08.30-09.00$ & Pengisian Daftar Hadir & Tim \\
\hline $09.00-09.15$ & Sambutan Ibu RT & Jessica \\
\hline 09.15-09.30 & Sambutan Ketua Panitia & Indri Susilawati, M.Fis \\
\hline 09.30-10.00 & Penyampaian Materi & Indri Susilawati, M.Fis \\
\hline 10.00-11.00 & Demostrasi Massage & Indri Susilawati, M.Fis \\
\hline 11.00-12.00 & Tanya Jawab & TIM \\
\hline
\end{tabular}

\section{HASIL KEGIATAN}

Kegiatan ini dilaksanakan pada tanggal 22 September 2019 yang melibatkan 15 peserta yang merupakan ibu-ibu Perumahan Muhajirin Asri 2.yang berasal dari berbagai latar belakang. Kegiatan ini dilaksanakan selama 1 hari yang terdiri dari penyampaian materi dan praktek massage secara langsung. Kegiatan ini bisa dikatakan sukses karena melihat antusias para peserta dalam melakukan praktek massage dan banyaknya pertanyaan yang di sampaikan oleh ibu-ibu. Seluruh anggota kepanitiaan berasal dari dosen FPOK IKIP Mataram, khususn ketua panitian merupakan seorang dosen sekaligus seorang praktisi fisioterapi.

\section{KESIMPULAN}

Kegiatan ini berjalan sesuai dengan yang diharapkan, beberapa peserta sudah mampu mempraktekkan apa yang telah di sampaikan oleh pemateri pada saat sesi praktek. Dengan adanya kegiatan seperti ini para ibu-ibu khusunya yang berada dilingkungan Perumahan Muhajirin Asri 2 lebih mengerti dan memahami pentingnya manfaat memberikan massage pada bayi dan anak balita.

\section{SARAN}

Kegiatan seperti ini dapat dilakukan pada skala yang lebih luas dan melibatkan banyak peserta.

\section{DAFRTAR PUSTAKA}

Aminarti, Dini. (2013). Pijat dan senam untuk bayi \& balita, cetakan ke-1. Yogyakarta: Brilliant Books.

Cheng, Carolynn D., Volk, Athony A., \& Marini, Zopito A (2011) Supporting Fathering Trough Infant Massage. The Journal Perinatal EducationVol 20, No. 4

Dasuki. (2003). Pengaruh pijat bayi terhadap kenaikan berat badan bayi umur 4 bulan.
Tesis magister, tidak diterbitkan. Yogyakarta: Universitas Gajah Mada.

Roesli, Utami. (2013). Pedoman Pijat Bayi. Jakarta: Pustaka Pembangunan Swadaya Masyarkat.

Sari, Anggrita. (2004). Pengaruh penyuluhan pijat bayi terhadap pengetahuan dan sikap ibu tentang pijat bayi di dusun dukuh desa sidokarto godean sleman, Skripsi tidak diterbitkan, Yogyakarta: 